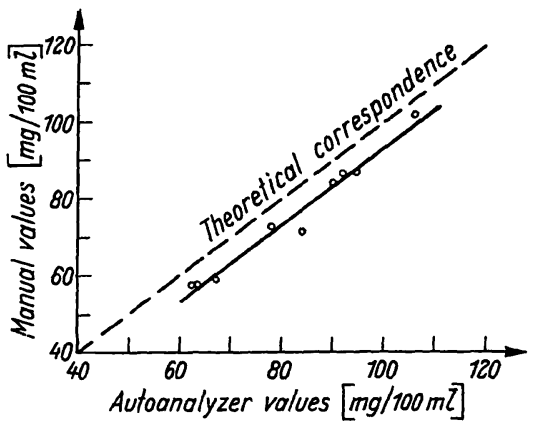

Fig. 5

Relation between manual and automatic values nine serum samples by both the classical manual method of WARREN and by the proposed automatic method. The results are shown in table 1 and figure 5 . As can be seen, the Autoanalyzer method gives consistantly higher results by about $8 \%$. This is most probably due to the incompleteness of the extraction of the coloured end product in the manual method.

Finally, we checked the effect of the most probable source of interference, namely the blood glucose. No interference could be detected by the addition of up to 10 times the normal amount of glucose.

This method has been in daily use in our laboratory for over a year and has been entirely satisfactory.

\title{
References
}

1. Ketelaer, $C_{H}$. J. und P. Delmotte, Acta neurol. psychiatr. Belg. 64, 441 (1964). - 2. BöнM, P., Dtsch. Zschr. Verdauungskrkh. 19, 65 (1959). - 3. Martensson, E., A. RAAL und L. Svennerholm, Biochim. biophysica Acta (Amsterdam) 30, 124 (1958). - 4. Svennerholm, L., Biochim. biophysica Acta
(Amsterdam) 24, 604 (1957). - 5. Mretrinen, T. und I. T. EAkKILuUkKainen, Acta chem. scand., 13, 856 (1959). - 6. WARren, L., J. biol. Chemistry 234, 1971 (1959). - 7. Courtors, J. E., Ann. biol. clin. (Paris) 21, 383 (1963). - 8. SAIfER, A. und S. Gertstenfeld, Clin. chim. Acta (Amsterdam) 7, 467 (1962).
P. Delmotte Melsbroek (Belgien) 16, tue van Heylen

\section{A Micromethod for the Routine Estimation of Inorganic Phosphate in Serum and Urine}

\author{
By A. J. Bastiaanse and C. A. M. Meijers \\ From the Clinical Laboratory, St. Anna Hospital (Direktor: Drs. C. A. M. Meijers) Geldrop, The Netherlands
}

(Eingegangen am 23. März 1967)

\begin{abstract}
A standard technique for the colorimetric determination of inorganic phosphate has been developed, based upon the work of ITAYA and UI, who found that Malachite Green at a low pH forms a complex with phosphomolybdate, which is measured at $660 \mathrm{~nm}$. The present method is different in that: 1. a lower concentration of Malachite Green is used, resulting in an analytically more suitable determination. 2. another stabilizing reagent is used. The present method has been applied to serum as well as urine.
\end{abstract}

Eine Standardmethode für die kolorimetrische Bestimmung von anorganischem Phosphat wird angegeben. Sie beruht auf der Arbeit von ITAYA und Ur, die fanden, daß Malachitgrün bei niedrigem pH einen Komplex mit Phosphomolybdat bildet, dessen Extinktion bei $660 \mathrm{~nm}$ gemessen wird. Die angegebene Methode unterscheidet sich von der von ITAYA und UI wie folgt: 1. Es wird eine geringere Malachitgrünkonzentration benutzt. Das ergibt eine analytische geeignetere Bestimmungsmethode. 2. Es wird ein anderes Stabilisierungsmittel vetwendet.

Die Methode kann zur Phosphatbestimmung in Serum und Harn angewandt werden.

Recently ITAYA and UI (1) introduced a new micromethod for the colorimetric determination of inorganic phosphate. Their procedure depends on the fact that Malachite Green at a low $\mathrm{pH}$ forms a complex with phosphomolybdate with a marked shift of the absorption spectrum. The colour developed is measured at $660 \mathrm{~nm}$. They reported determinations of percentage recovery with serum, and they compared the method with those of Fiske and Subbarow (2) and Martin and Doty (3), but only a few experimental figures were given.

In the present paper we have examined some aspects of the work of ITAYA and Ur. First we followed their standard procedure by pipetting $0.05 \mathrm{~m} /$ serum, standard or water into $4 \mathrm{~m} l 5 \%$ perchloric acid, adding $1 \mathrm{ml}$ of the centrifugate to $5 \mathrm{~m} l$ colour-developing reagent, immediately followed by $0.2 \mathrm{ml} 1.5 \%$ Tween 20 solution. The optical density was measured at $660 \mathrm{~nm}$ after $10 \mathrm{~min}$.

Later however, we modified their standard procedure by using a lower concentration of Malachite Green and a different stabilizing reagent. Our method gives precise and reproducible results when applied to serum as well as urine.

\section{Method}

Materials

Reagents

All reagents were analytical grade and included $\mathrm{KH}_{2} \mathrm{PO}_{4}$ (for the preparation of standards), $70 \%$ perchloric acid, $\left(\mathrm{NH}_{4}\right)_{6} \cdot \mathrm{MoO}_{24} \cdot$ - $4 \mathrm{H}_{2} \mathrm{O}$, Malachite Green and $37 \% \mathrm{HCl}$, all from Merck AG, Tween 20 (polyoxyethylene sorbitan monolaurate) from J. A. Boòm, 
Meppel, Holland; and Sterox SE (a nonionic polyoxyethylene thioether) from Hartman-Leddon Cie, U. S.

Redistilled water was used throughout these experiments. Optical density was measured with the Vitatton UC 200 colorimeter. Absorption spectra were measured with the Unicam SP 500 spectrophotometer.

\section{Colour-stabilizing reagent}

According to ITAYA and Ur the colour of the phosphomolybdate complex is rendered stable by adding Tween 20 at a final concentration of $0.05 \%$ immediately after the colour develops. The addition of detergent prior to the colorimetric reagent is not advisable because this retards formation of the complex.

We have confirmed these results. In addition, we have found the same retardation of complex formation when the colorimetric reagent and Tween 20 solution were added together in the required concentration to the sample containing phosphate. Because Tween 20 ist not normally available in a clinical laboratory, we started experiments with a detergent which is often used in flame photometry, viz., sterox. $8 \mathrm{ml}$ of a $2 \%$ sterox solution were added to $400 \mathrm{~m} /$ of colorimetric reagent, prepared according to ITAYA and Ur. This gives a final concentration of $40 \mathrm{mg}$ sterox per $100 \mathrm{~m} /$. This mixture was now used as the colorimetric reagent and, of course, no Tween 20 was added.

A straight line was obtained for the concentration-range of 1 to $10 \mathrm{mg} \%$ phosphate; the absorption spectrum showed a maximum between 640 and $660 \mathrm{~nm}$. The same results are obtained with Tween 20, but sterox can be added together with the colorimetric reagent, while Tween 20 cannot. From a routine point of view, this is more convenient than pipetting the detergent afterwards.

\section{Concentration of Malachite Green}

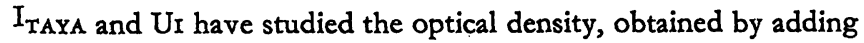
$1 \mu \mathrm{g}$ of inorganic phosphate to the acidified solution of dye and ammonium molybdate. They plotted the optical density against the final concentration of $\mathrm{HCl}$ at three different concentrations of the dye, viz., $0.5 \%, 0.2 \%$ and $0.05 \%$. The authors showed that for all three concentrations of Malachite Green a final concentration of 1N $\mathrm{HCl}$ was suitable, but for their standard procedure they chose a final concentration of $0.12 \%$ Malachite Green $(0.2 \%$ solution as reagent), which produces a blank optical density of about 0.180 .

We have found that $0.045 \%$ is the lowest possible concentration of Malachite Green, that gives a linear standard curve with a sterox concentration of $40 \mathrm{mg} / 100 \mathrm{ml}$ (Figs. 1 and 2). The blank optical density is 0.025 to 0.030 . The absorption spectrum shows a maximum between 640 and $660 \mathrm{~nm}$. (Fig. 3).

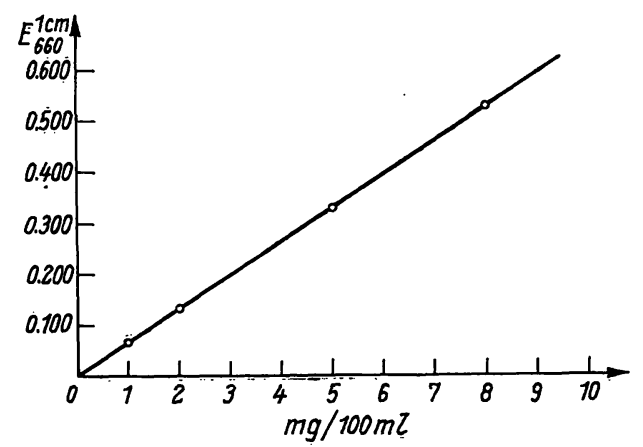

Fig. 1

Standard curve. The standard procedure was applied to the standard solutions containing 1 to $8 \mathrm{mg} \%$ (expressed as $\mathrm{P}_{\mathrm{i}}$ ) phosphate

\section{Concentration of sterox and stability}

We have made experiments with several concentrations of sterox in order to get both a linear standard curve and good stability. Stability is expressed as the difference in optical density $(660 \mathrm{~nm})$ of the same solution, measured after 10 and $30 \mathrm{~min}$. With $40 \mathrm{mg}$ sterox per $100 \mathrm{~m} /$ colorimetric reagent, standard solutions contain-

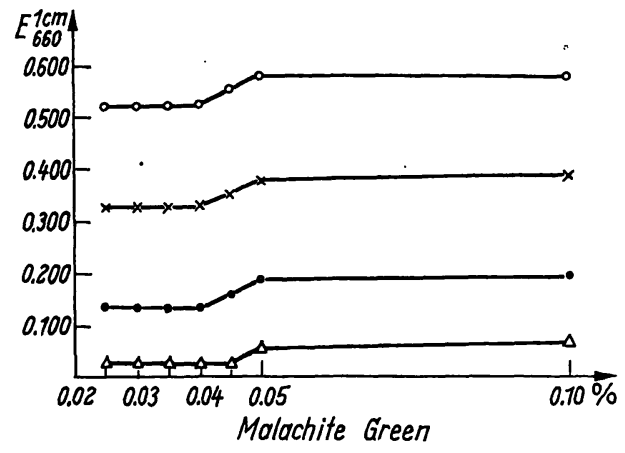

Fig. 2

Absorption of blank and standard solutions, plotted against different concentrations of Malachite Green.
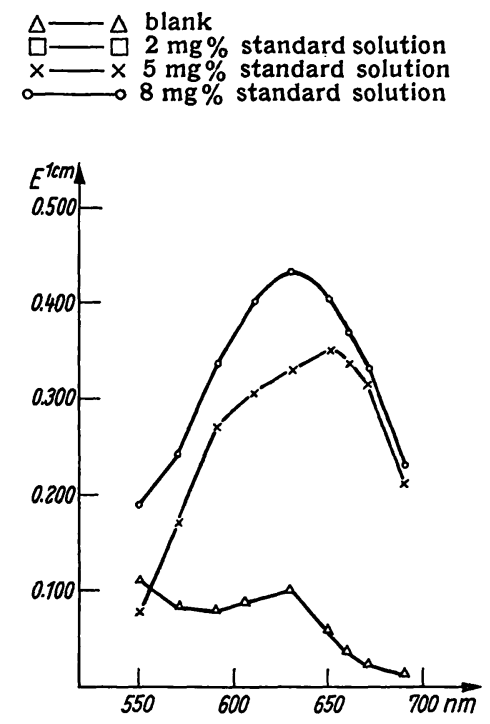

Fig. 3

Absorption of $5 \mathrm{mg} \% \mathrm{P}_{\mathrm{i}}$ standard solution.

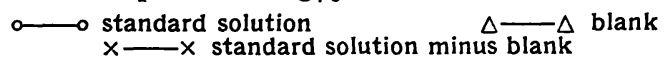

ing 2 and $5 \mathrm{mg} \%$ phosphate remained entirely stable, while $8 \mathrm{mg} \%$ phosphate appeared somewhat less stable (mean difference in O. D. between 10 and $30 \mathrm{~min}$. of 0.010 ).

Linear curves were also obtained with lower sterox concentrations, i. e. 10 and $20 \mathrm{mg} / 100 \mathrm{~m} /$, but then the stability was reduced. Higher sterox concentrations, e. g. $80 \mathrm{mg} / 100 \mathrm{~m} /$ produce a higher blank optical density, whereas concentrations lower than $40 \mathrm{mg} /$ $100 \mathrm{~m} /$ do not further lower the blank optical density.

The standard technique

\section{Colorimetric reagent}

1 vol. of $4.2 \%\left(\mathrm{NH}_{4}\right)_{6} \cdot \mathrm{MoO}_{24} \cdot 4 \mathrm{H}_{2} \mathrm{O}$ in $4.5-5.0 \mathrm{~N}$ $\mathrm{HCl}$ is mixed with 3 vol. of $0.045 \%$ Malachite Green. After $30 \mathrm{~min}$. the mixture is filtered and the $2 \%$ sterox solution is added $(8 \mathrm{ml}$ per $400 \mathrm{ml}$ colour-developing reagent, final concentration $40 \mathrm{mg} / 100 \mathrm{ml}$ ).

The reagent is stored at $4^{\circ} \mathrm{C}$, but when used must be at room temperature. The reagent must be freshly prepared every week.

\section{Procedure}

$0.05 \mathrm{~m} /$ serum, standard or water is pipetted into $4 \mathrm{ml}$ $5 \%$ perchloric acid and the solution is mixed. After centrifuging $5 \mathrm{ml}$ of the colorimetric reagent is added to $1 \mathrm{~m} l$ clear supernatant and the solution is mixed. The 
optical density is measured at $660 \mathrm{~nm}$ after $10 \mathrm{~min}$. It is essential, for the preparation of all reagents as well as for the procedure, that distilled water is used. Demineralized water may contain phosphorus, depending on the state of saturation of the resin column. The $\mathrm{HCl}$ must not be below $4.5 \mathrm{~N}$, for then the complex becomes unstable.

\section{Comparison with the method of TAUSSKY and SCHORR}

We have compared the data obtained with the present method with data obtained from the same sera by the colorimetric method of TAUSSKY and SCHORR (4), which employs molybdate and MoHrs salt.

Figure 4 shows data obtained from 30 sera. Blanks, standards and sera were all measured in duplicate. It will be clearly seen that both methods give the same result. However, the present method uses only $0.05 \mathrm{ml}$ serum per determination, in contrast with $0.5 \mathrm{~m} l$ serum for the other method.

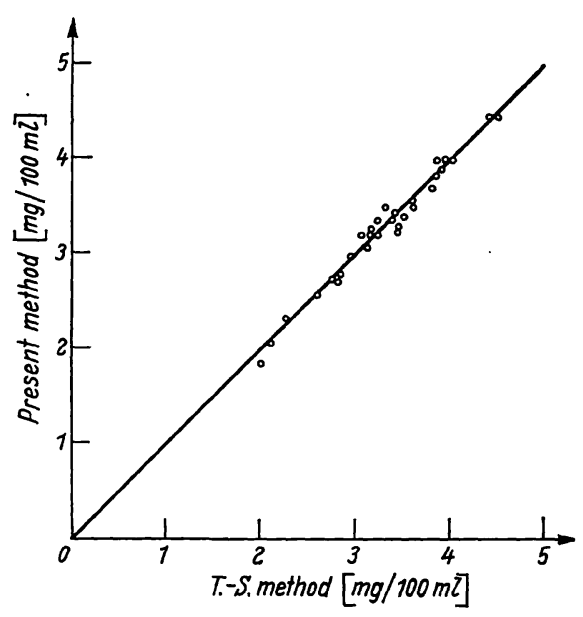

Fig. 4

Comparison of the present method with the method of TAUSSKY and SCHORR

\section{Determination of phosphate in urine}

For the determination of inorganic phosphate in human urine by the method of TAUSSKY and SCHORR, the urine is acidified with $\mathrm{HCl}$ against Congo paper, and then diluted 1:100 with distilled water.

In the present method the urine is acidified in the same way, but is diluted 1:5. Sometimes, when a special diet low in phosphate has been prescribed, another dilution may be more suitable.

\section{Standard technique for urine}

The same colorimetric reagent is used as with serum. Procedure: $0.01 \mathrm{~m} l$ urine (1:5 diluted with distilled water), standard or water is pipetted into $4 \mathrm{~m} / 5 \%$ perchloric acid and the solution is mixed. To $1 \mathrm{ml}$ of this solution, $5 \mathrm{ml}$ colorimetric reagent is added and the optical density is measured at $660 \mathrm{~nm}$ after $10 \mathrm{~min}$.

When much protein is present the solution must be centrifuged. The presence of large amounts of glucose does not affect the determination.

Comparison of the present method for urine with the TAUSSKY-SCHORR metbod

Figure 5 shows the result of 18 urine determinations. Again it will be seen that both methods give the same results, except that the present method gives higher values for phosphate concentrations

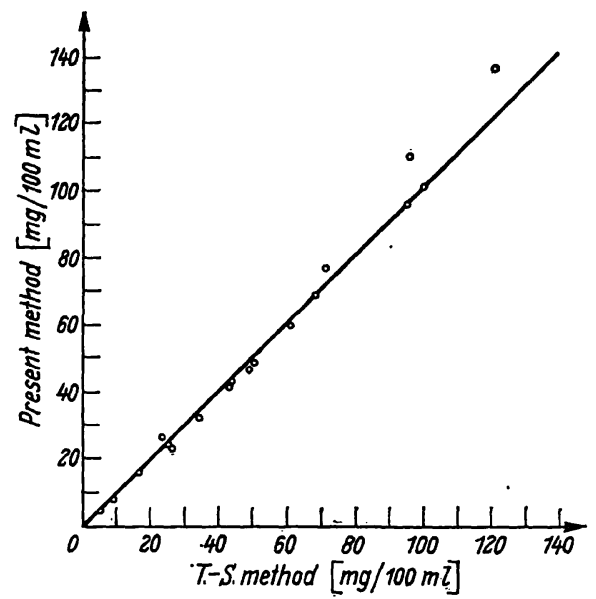

Fig. 5

Comparison of the present method for urine with the method of TAUSSKY and SCHORR

above $100 \mathrm{mg} \%$. Phosphate concentrations from $5-200 \mathrm{mg} \%$ produce an optical density of 0.040 to 0.500 with our method, compared with 0.040 to 1.250 with the TAUSSKY-SCHORR method. This means that, using the latter procedure, the urine must be diluted further when high amounts of inorganic phosphate are initially measured, which is equivalent to repeating the determination. This could not arise with the present method.

\section{Discussion}

It is obvious that the real advantage of the method of ITAYA and UI, compared with the method of TAUSSKY and SCHORR, is the much smaller amount of serum which is required for one determination. $(0.05 \mathrm{ml}$ instead of $0.5 \mathrm{ml}$.)

That was the main reason why we decided to examine critically some aspects of their work.

We have introduced a new standard technique, giving precise and highly reproducible results when applied to serum as well as urine. The present method differs firstly, in that a lower concentration of Malachite Green is used. A dye concentration of $0.045 \%$ gives the lowest possible blank value, resulting therefore in an analytically more suitable technique. Higher Malachite Green concentrations are not necessary to form the dye-phosphomolybdate complex; they only produce higher optical density values.

Another important advantage of our colorimetric reagent is that it does not stain the hands of the analysts engaged on this routine work.

The colour reagent of ITAYA and Ur, containing $0.2 \%$ Malachite Green, produces dark green spots on the skin which are not easily removed by washing and are still present after some hours. In the second place we used another stabilizing reagent, sterox, which is often used and therefore always available in a clinical laboratory. From a routine point of view it is important that sterox can be added to the colour-developing reagent, which then may be stored and used as such, while Tween 20 cannot. At the moment we are examining the possibility of determining the lipid-bound phosphorus of serum, starting with the protein precipitate obtained with perchloric acid. 


\title{
References
}

1. ItayA, K. and M. Ur, Clin. chim. Acta (Amsterdam) 14, 361 (1966). - 2. Fiske, C. H. and Y. Subbarow, J. biol. Chemistry 66, 375 (1925). - 3. Martin, J. B. and D. M. Doty, Analytic.
Chem., 21, 965 (1949). - 4. TAusskx, H. H. and E. Schorr, J. biol. Chemistry, 202, 675 (1953).
Drs. A. J. Bastiaanse Geldrop (Niederlande) St. Anna Hospital

\section{Automatisierung der Glucosebestimmung mit o-Toluidin}

\author{
Von K. LEYBold \\ Aus der II. Medizinischën Universitätsklinik und Poliklinik Kiel (Direktor: Prof. Dr. L. Weissbecker)
}

(Eingegangen am 12. April 1966)

Die Anpassung der Glucosebestimmung mit o-Toluidin an die tageszeitlich verschiedenen Anforderungen einer Klinik wird beschrieben. Blut wird in Mikroröhrchen in Trichloressigsäure durch hochtourige Zentrifugation in wenigen Sekunden enteiweißt, der Ủberstand vom Probennehmer des Autoanalyzers direkt über dem Sediment zur automatischen photometrischen Bestimmung entnommen. Wesentliche technische Merkmale sind ein zur Aufnahme von Mikroröhrchen veränderter Probenteller, das Fehlen des Dialysators und die Verwendung von säurefestem Siliconschlauch in der Pumpe und als allgemeinem Verbindungsschlauch im Autoanalyzer. Für Einzelbestimmungen kann eiweißfreier Uberstand aus den gleichen Probenröhrchen von Hand entnommen werden. Präzision und Empfindlichkeit der Methode, besonders im niedrigen Konzentrationsbereich, sind gut.

The determination of glucose with o-toluidine was adapted to the daily varied requirements of the hospital. Blood is deproteinised in a few seconds by treatment with trichloracetic acid in microcentrifuge tubes, followed by high speed centrifugation. The supernatant is taken directly from above the sediment by the crook of the autoanalyser, and the photometric determination then procedes automatically. The essential features of this technique are the modification of the sample plate to receive micro-tubes, the ommission of the dialyser, and the use of acid-resistant silicone tubing in the pump and generally for other connections. For individual measurements, deproteinised supernatant can be sampled from the same tubes for quantitative determinations by hand. The precision and sensitivity of the method are good, especially at low concentrations.

Die kolorimetrische Bestimmung der Blutglucose mit oToluidin nach HULTMANN (1) besticht durch ihre einfache Technik, gute Spezifität und Empfindlichkeit. Sie wurde mehrfach bearbeitet $(2,3,4)$. Testpackungen sind im Handel. ZENDER (5) hat die Methode an den Autoanalyzer angepaßt. Der Aufwand und die geringe Analysenfrequenz haben uns veranlaßt, diese Bestimmung im Autoanalyzer einfacher, schneller, rentabler und dabei empfindlich zu gestalten und sie unseren Klinikbelangen mit sehr unterschiedlichen zeitlichen und zahlenmäßigen Anforderungen anzupassen.

\section{Methodik}

\section{Prinzip}

Zunächst geben wir, wie für die Handmethode beschrieben, Kapillarblut in Trichloressigsäure. Dieses Gemisch liefert, in Mikroanalysenröhrchen wenige Sek. hochtourig zentrifugiert, ein festes Sediment und einen klaren Überstand. Wahlweise können wir nun, wie üblich, einen Teil des Überstandes zur Glucosebestimmung von Hand mit o-Toluidin versetzen, erhitzen und nach kurzer Kühlung im Photometer analysieren (bei wenigen Bestimmungen) oder direkt vom Probennehmer des Autoanalyzers aus den gleichen Röhrchen abhebern lassen (bei vielen Bestimmungen), wobei die Dialyse eingespart wird.

\section{Geräte und Cbemikalien}

Autoanalyzer (Ștandardaussührung mit Zwischenspülung ohne Dialysator mit Filter $625 \mathrm{~nm}$ und Nockenscheibe zur Entnahme von 40 Proben pro Std.) der Fa. Technicon, Chertsey/England, mit selbstgefertigter, $1 \mathrm{~cm}$ dicker Plexiglasscheibe auf dem Probenteller zur Aufnahme der Mikroröhrchen (s. u.) in randständigen Löchern von $11 \mathrm{~mm}$ Durchmesser und Siliconschlauchergänzung (s. Fließschema).

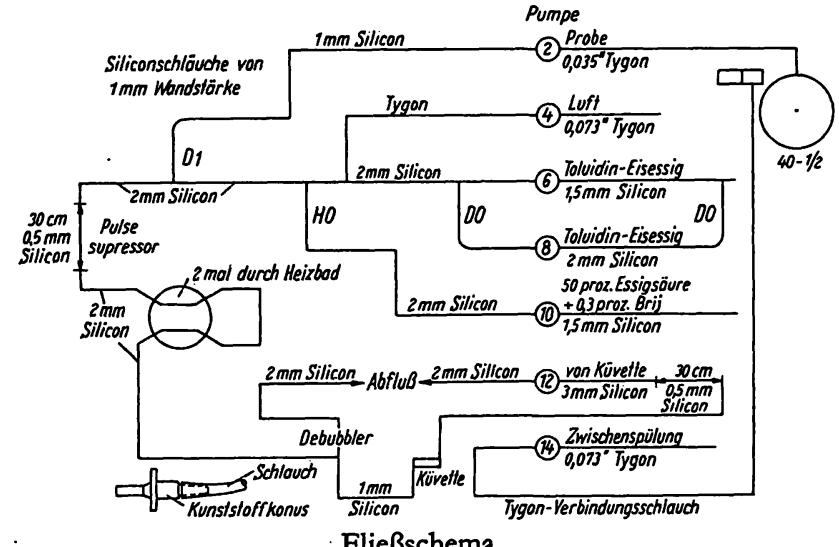

Fließschema

Mikrozentrifuge und Mikroanalysentöhrchen aus Polypropylen der Fa. Eppendorf-Gerätebau, Hamburg.

Siliconschlauch von $1 \mathrm{~mm}$ Wandstärke mit verschiedenem Innendurchmesser (Abb.) der Fa. Rehau Plastics GmbH in Rehau/ Bayern. Die Pumpenschläuche aus Silicon sollen $15,5 \mathrm{~cm}$ lang sein; sie; werden mit Kunststoffverbindungsstücken mit Rekordkonus der Fa. Braun/Melsungen in den beiden Schlauchhalterungen der Schlauchpumpe fixiert (Abb.), die in ihren äußeren Löchern befestigt werden.

Gerät zur Kapillarblutentnahme.

Trichloressigsäure p. a., o-Toluidin puriss. p. a. von Fluka.

Essigsäure reinst, 99-100 proz., Thioharnstoff p. a., Benzoesäure p. a., Brij 35 von Technicon.

$\mathrm{D}(+)$ Glucose $\cdot \mathrm{H}_{2} \mathrm{O}$.

\section{Lösungen}

3 proz. Trichloressigsäure ${ }^{1}$.

Toluidinreagens ${ }^{1}$ ): in 1 / Eisessig werden $3 \mathrm{~g}$ Thioharnstoff gelöst, dann $100 \mathrm{~m} l o$-Toluidin zugefügt (braune Flasche).

1) Die Fa. E. Merck, Darmstadt, liefert Fertigreagenzien. 